\title{
Scientific Reasoning Abilities in Religion Major on Biology Course to Utilize the Project-Based Learning
}

\author{
$1^{\text {st }}$ L Luzyawati \\ Biology Education Departmen \\ Universitas Wiralodra \\ Indonesia \\ lesy.luzyawati@unwir.ac.id
}

\author{
$2^{\text {nd }}$ I Hamidah \\ Biology Education Departmen \\ Universitas Wiralodra \\ Indonesia
}

\author{
$3^{\text {rd }}$ A Ratnasari \\ Biology Education Departmen \\ Universitas Wiralodra \\ Indonesia
}

\begin{abstract}
The Curriculum 2013 facilitates students to learn across subjects of interest, such as students in the religious department at Madrasah Aliyah Negeri (State Islamic Senior High School) 1 in Indramayu to take biology matter. Biology is closely related to scientific phenomena to develop student abilities, including scientific reasoning. The study aims to analyze the scientific reasoning abilities of religious students majoring in biology learning through project-based learning models. This research used one class with 24 students. The data concerning scientific reasoning abilities were obtained observation and test. The data analysis represented that scientific reasoning abilities integrated level at a good, advance at an enough, and culminating at a less category. Project-Based Learning was an effective learning model to utilize in biology learning to improve scientific reasoning.
\end{abstract}

Keywords—Religion Major, Biology, Project Based Learning

\section{INTRODUCTION}

The implementation of the 2013 curriculum is the actualization of the curriculum in learning and the formation of students' competencies and characters [1]. The 2013 curriculum facilitates students of other programs to study cross-interest subjects, such as Madrasah Aliyah (Islamic Senior High School) students, for studying biology subjects matter. Biology is closely related to scientific phenomena to be able to develop students' skills, including scientific reasoning abilities.

The reasoning is one aspect of human intelligence [2]. Scientific reasoning can be interpreted as a set of abilities needed to conduct scientific inquiries in the order of abilities related to the collection and analysis of evidence, and use it to construct cohesive evidence-based arguments [3] [4]. Scientific reasoning can also be interpreted as a part of critical thinking skills (cognitive and metacognitive processes) [5]. Several studies of scientific reasoning are the basis for identifying the development of cognitive processes [6].

Not only scientists today but also students who will become future scientists much need the ability of scientific reasoning. The base of scientific reasoning abilities is increasingly essential for making decisions in everyday life and for participating in social life. Scientific reasoning needs to be trained and fostered in the educational process, especially in science education. The educational process needs exercise and guided by scientific reasoning, especially in science education [7].

A student's scientific reasoning is very complicated, but it cannot be honed well when the curriculum or learning process is not appropriate [8]. The need to know the level of scientific reasoning in students to provide appropriate teaching. If the level of scientific reasoning of Senior High School or Islamic Senior High School students is still at a hunk of concrete and transitional operational level, then they will find it challenging to accept abstract concepts [9]. This situation has an impact when they continue their studies to the next level; the level of scientific reasoning of students is proportional to the level of prior knowledge [5]. The learning process becomes an essential factor in improving scientific reasoning, so that teacher innovation in learning becomes the primary key. Without innovative development in education, no quality improvement has been achieved [2], one of which is increasing scientific reasoning abilities.

Several learning models can improve scientific reasoning abilities, including inquiry-based laboratories [4], modeling cycles [10], computerize learning games [11]. Scientific reasoning can also be improved using the concept map [12]. However, there is still little research on the effects of learning with project-based learning models on scientific reasoning in learning biology, especially the concept of excretion.

The project-based learning model is considered to be fun, contextual, effective, efficient, and meaningful and also recognizes the diversity of students' potentials so that they can carry out exploration activities [13]. Giving projects to students can stimulate them to think in scientific inquiry. Some indicators of scientific reasoning include control variables, hypothetical-deductive reasoning, causal and correlational reasoning, proportions, and ratios on inductive deductive reasoning, and probabilistic reasoning [14]. 
Another opinion is that there are 16 frameworks in scientific reasoning that are modified because they have integration with Bloom's revised taxonomy and science process skills [15]. The ability of scientific reasoning hopefully to be seen when learning with project-based learning that is when students design a kidney analog media to explain the process of urine formation.

This study aims to look at the categories of scientific reasoning abilities of religious major students on the concept of excretion in the process of learning biology, whether the categories class is classified into the level of integrating, advance, or culminating. Besides that, it aims to find out the effectiveness of the project-based learning model in learning excretion in increasing scientific reasoning ability. The syntax of the project-based learning model used in this study adopts from The George Lucas Educational Foundation namely, start with essential questions, design a plan for the project, create a schedule, monitor the student and the progress of the project, assess the outcome, evaluate the experience [16].

\section{RESEARCH METHOD}

This study focuses on student at Madrasah Aliyah Negeri (State Islamic Senior High School) 1 Indramayu, West Java Province, Indonesia. The sample came from one of the XI classes majoring in religion as many as 24 students taking biology subjects. The material concept is a kidneys excretion, including kidneys and nephron structure, the process of urine formation, any factors that can affect the level of urine, and also disorders or abnormalities of kidney excretion system. Previously students worked on questions in the form of a pretest before learning began. Learning begins with the phenomenon of irregularities in the urine, such as facts about diabetes mellitus, diabetes insipidus, albuminuria. They are pushed to think by being given several questions so that they feel curious as to why this can happen. Next, introducing students to know the structure of the kidney and nephron, including the parts inside. Each student holds a Worksheet to assist students in designing the nephron analogy model in the process of urine formation. Each group of students determines the tools and materials needed to make analogous models and create their shapes. They have two weeks to complete this project. After that, each group presents the results of their project and evaluates their work.

The scientific reasoning data of students are assessed during the learning process by the observer and also the end of learning by doing posttests. Many instruments can be used in assessing scientific reasoning, including Scientific Reasoning Test Version 9 [17], Test of Scientific Literacy Skills (TOSLS) [18] and The Lawson's Classroom Test of Scientific Reasoning (LCTSRS) ) [19]. This research does not use all three, but instead makes instruments that refer to the framework for scientific reasoning [15]. The scientific reasoning framework assessed can be seen in table I.

TABLE I. FRAMEWORK FOR SCIENTIFIC REASONING

\begin{tabular}{|c|c|c|}
\hline Category & $\begin{array}{l}\text { Levels in Bloom's } \\
\text { Taxonomy }\end{array}$ & Science Process Skills \\
\hline \multirow[t]{4}{*}{ Integrated } & \multirow[t]{4}{*}{ Analysis } & Define a problem to learn \\
\hline & & Defines precisely the system to be studied \\
\hline & & Design and conduct controlled scientific investigations \\
\hline & & Establish stages that use logic \\
\hline \multirow[t]{3}{*}{ Advanced } & \multirow[t]{3}{*}{ Evaluation } & $\begin{array}{l}\text { Determining whether the chosen one is the answer to a problem or question } \\
\text { determines the size and or unit }\end{array}$ \\
\hline & & $\begin{array}{l}\text { Summarizing for logical purposes justifies the basis for conclusions from } \\
\text { empirical evidence }\end{array}$ \\
\hline & & Use causal reasoning to distinguish co-incidence from cause and effect \\
\hline \multirow[t]{9}{*}{ Culminating } & \multirow[t]{4}{*}{ Evaluation } & Conclude logically from empirical evidence \\
\hline & & Use causal reasoning to distinguish chance from cause and effect \\
\hline & & Using data and mathematics in solving real-world problems \\
\hline & & Use proportional reasoning to make predictions \\
\hline & \multirow[t]{5}{*}{ Synthesis } & Generate and evaluate analogies \\
\hline & & Generate predictions through the process of deduction \\
\hline & & Think analogy \\
\hline & & Thinking to assimilate the concept \\
\hline & & Think deliberately \\
\hline
\end{tabular}

Observation data and test results are analyzed, then grouping them into various scientific reasoning categories. To obtain a score of scientific reasoning, that is, by finding out the percentage of mastery of scientific reasoning. The criteria of percentage of scientific reasoning presented in Table II.

TABLE II. CRITERIA FOR SCIENTIFIC REASONING

\begin{tabular}{|c|c|}
\hline Percentage & Criteria \\
\hline $86 \%<\mathrm{P} \leq 100 \%$ & Very Good \\
\hline $75 \%<\mathrm{P} \leq 85 \%$ & Good \\
\hline $60 \%<\mathrm{P} \leq 75 \%$ & Enough \\
\hline $54 \%<\mathrm{P} \leq 60 \%$ & Less \\
\hline $\mathrm{P} \leq 54 \%$ & Very Less \\
\hline
\end{tabular}


Besides, to see the effectiveness of the project-based learning model of learning in biology on the concept of excretion, the test result data is processed with one-sample TTest because the data showed the normal distribution.

\section{RESULT AND DISCUSSION}

The ability of scientific reasoning in class XI students at MAN 1 Indramayu recorded through observation and tests. The average results listed in Table III.

TABLE III. RESULTS OF STUDENT SCIENTIFIC REASONING

\begin{tabular}{|c|c|}
\hline Aspect & Average \\
\hline Integrated & 72 \\
\hline Advance & 68,5 \\
\hline Culminating & 37,5 \\
\hline
\end{tabular}

Table 3 shows that scientific reasoning abilities in all three aspects are in different categories. Students' scientific reasoning abilities of the integrated-aspect are at a good level. The high ability is due to students designing their nephron analog media used in the process of forming urine. Besides that, in the integrated aspect, also students are invited to be able to define the concepts to be learned by giving a few questions to identify problems related to the excretion system.
All aspects of scientific reasoning can be identified by problem-solving activities[20].

The ability of the scientific reasoning of students in the advanced aspects belongs to the medium category. In this aspect, students are invited to evaluate analogous models created by the process of urine formation and its abnormalities. The ability of students' reasoning on this aspect is still fairly moderate because students also have not been able to prove the reabsorption event involving the blood vessels, so they have not been able to prove empirically.

The ability of scientific reasoning on culminating aspects is very poor. In this aspect, students must be able to use causal reasoning, proportional reasoning, evaluate analogies, and think analogies. Analogy reasoning is the process of drawing conclusions that discuss objects, events, or concepts based on the similarity of relationships between things being compared [21]. The ability of reasoning is a thinking skill that can emerge if it is trained in learning continuously. Thinking skills are not an instant learning outcome that can be directly measured by two to three times the learning then expressed whether or not [22].

Figure 1 shows a comparison of students' Scientific reasoning abilities based on observations and tests in more detail.

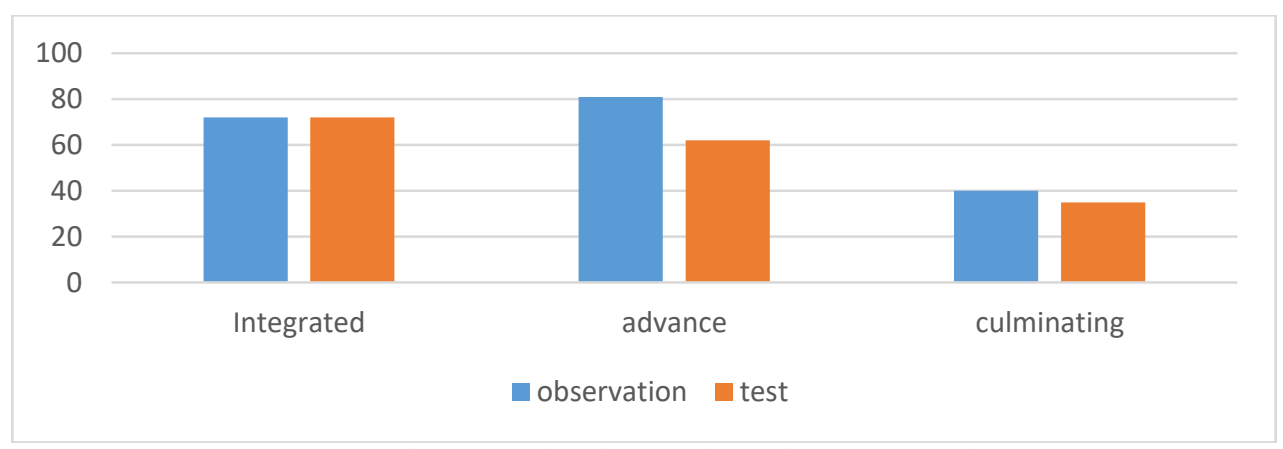

Fig. 1. Comparison of students' scientific reasoning abilities on observations and tests

Figure 1. shows that the scientific reasoning ability of students in the integrated category, both the observation results and test results, is in proper criteria. Both received a percentage value of $72 \%$. At this stage, students presented with problems that are then associated with the concepts to be learned and also think of making a design analogy of the process of urine formation. The syntax of starting with essential questions and design a plan for the project in the project-based learning model facilitates students in scientific reasoning in the integrated or equivalent category by analyzing the bloom taxonomy level. This scientific reasoning ability included in critical thinking skills [23], and learning by using project-based learning models can develop students' critical thinking skills [24].

In the advanced category, there is a difference between the observation results and the test results. Observation results have a higher percentage of scores compared to test results. Scientific reasoning that assessed at the time of observation is the result of the group's image. Each group tries to link the nephron analog media that they make with the actual process of urine formation. The disadvantage is selfperformance during a presentation of the concept; not every member understands what they presented so that when each student tested to measure his ability, the results are smaller than the observation results. The reason, there is no individual responsibility for each other, so some students rely on some other students in the group. Even though, when students have to solve posttest questions, it being their selves. Responsibility always depends on students and emphasizes students to be able to construct their understanding or concept [25].

Another reason why the average advance value is smaller than the average value at the integrated level is that if it is associated with the level on the bloom taxonomy, this advance category included at the evaluation level. One level higher than the level of analysis. The ability to evaluate is 
related to the ability to provide an assessment of the solutions and methods used in answering questions and to criticize arguments [26]. However, students have difficulty in answering questions by evaluating categories. This can be because students do not understand the purpose of the statement correctly [27].

The level of evaluating is also in the culminating category in scientific reasoning. The difference is related to the science process skills presented. In the culminating category, students can think logically, find cause and effect, solve problems in the real world, and predict. In other word means that in this category, students can find the advantages and disadvantages of analog media that they make. They also have found the correct concept of the excretion system and related it to abnormalities/diseases that arise when there are physiological errors. This ability can be seen at the syntax of assessing the outcome and evaluating the experience. At this stage, each group presented the workings of the analog nephron model they made and their advantages and disadvantages. This happens because of the ability of scientific reasoning, students can assess and predict, and solve problems in learning projects making analog media nephron. Learning with project-based learning can enhance students 'ability to solve problems in their scientific processes skill so that they can also improve students' scientific reasoning abilities.
Project-based learning also encourages students to think deeply so that students' thinking abilities can develop well.

The culminating category is also at the synthesis level, which is the highest level in the bloom taxonomy. At this level, students must have to be able to think analogies, evaluate analogies, and assimilate concepts. Through analog media created, students can relate the structure and function of nephrons, the processes that occur in nephrons, the factors that influence how they work, and the abnormalities that occur. This is under factors that influence scientific reasoning, namely the ability to think analogically students are thinking by equating or comparing phenomena that are by the real [28]. Logical thinking is that students in their activities think according to patterns, and students must also be able to think analytically, that is, students' thinking activities that are following certain steps in learning to make analogy media. This scientific reasoning ability as per the ability of students to form their knowledge or assimilate concepts from the results of learning experiences in making media analogies [29]. Besides, by thinking analogy students can foster scientific reasoning in education as meta-analytic evidence and solve problems using reason [7].

The effectiveness of the project-based learning model in learning on the concept of excretion is also seen from the normalized gain (n-gain). The effectiveness test data listed in table IV.

TABLE IV. EFFECTIVENESS TEST RESULTS

\begin{tabular}{|c|c|c|c|}
\hline Pretest average & Postest average & N-gain & Category \\
\hline 56,3 & 21 & 0,45 & medium \\
\hline
\end{tabular}

Table IV shows that the use of project-based learning models can improve students' scientific thinking skills in the medium category. Learning activities in groups to work together in making projects make students look for a variety of literature, share information, and make project designs that are consistent with theory. These activities can train students in thinking and connecting concepts. Also, students can use their thinking skills and reasoning, to understand information to form their deep concepts [30]. One that can improve students' reasoning abilities is the use of appropriate learning methods or models [31], among them inquiry-based learning models. Inquiry-based inquiry can make a big change in the ability of students' scientific reasoning [32] and then problem-solving learning models can also make students reason based on their previous knowledge to connect their past experiences with new situations [33]. Likewise, with the project-based learning model, an increase in the ability to think scientifically, it means that the project-based learning model is effective in increasing the ability to think scientifically.

\section{CONCLUSION}

In summary, learning after using a project-based learning model, students can improve their scientific reasoning abilities. The analysis of students' scientific reasoning abilities is in the integrated aspect at a good category, advance at an enough category, and culminating at a less category. This research shows that project-based learning can stimulate students to think in scientific inquiry.

\section{REFERENCES}

[1] C. Panjaitan, "Analisis Minat Belajar Biologi pada Rumpun Lintas Minat Berdasarkan Implementasi Kurikulum 2013 pada Siswa Kelas X SMA Negeri 5 Kota Jambi,” Artik. Penelitian. Jambi Univ. Jambi, 2014.

[2] B. E. Yanto, B. Subali, and S. Suyanto, "Measurement Instrument of Scientific Reasoning Test for Biology Education Students.," Int. J. Instr., vol. 12, no. 1, pp. 1383-1398, 2019.

[3] K. Koenig, M. Schen, and L. Bao, "0942573_Schen_ScEd2012," 2012.

[4] Ö. Acar, "Scientific reasoning, conceptual knowledge, \& achievement differences between prospective science teachers having a consistent misconception and those having a scientific conception in an argumentation-based guided inquiry course," Learn. Individ. Differ., vol. 30, pp. 148-154, 2014, doi: 10.1016/j.lindif.2013.12.002.

[5] J. E. Dowd, R. J. Thompson, L. A. Schiff, and J. A. Reynolds, "Understanding the complex relationship between critical thinking and science reasoning among undergraduate thesis writers," $C B E$ Life Sci. Educ., vol. 17, no. 1, 2018, doi: 10.1187/cbe.17-03-0052.

[6] D. L. Barz and A. Achimaş-Cadariu, "The development of scientific reasoning in medical education: A psychological perspective," Clujul Med., vol. 89, no. 1, pp. 32-37, 2016, doi: 10.15386/cjmed530 .

[7] Y. Maryuningsih, T. Hidayat, R. Riandi, and N. Y. Rustaman, "Penerapan analogi pada perkuliahan genetika untuk menumbuhkan keterampilan penalaran ilmiah (scientific reasoning), $J$. 
Bioedukatika, vol. 6, no. 2, p. 59, 2018, doi: 10.26555/bioedukatika.v6i2.9429.

[8] E. Dolan and J. Grady, "Recognizing students' scientific reasoning: A tool for categorizing complexity of reasoning during teaching by inquiry," J. Sci. Teacher Educ., vol. 21, no. 1, pp. 31-55, 2010, doi: 10.1007/s10972-009-9154-7.

[9] J. C. Moore and L. J. Rubbo, "Scientific reasoning abilities of nonscience majors in physics-based courses," Phys. Rev. Spec. Top. - Phys. Educ. Res., vol. 8, no. 1, pp. 1-8, 2012, doi: 10.1103/PhysRevSTPER.8.010106.

[10] A. N. Stammen, K. L. Malone, and K. E. Irving, "Effects of modeling instruction professional development on biology teachers' scientific reasoning skills," Educ. Sci., vol. 8, no. 3, 2018, doi: 10.3390/educsci8030119.

[11] D. F. Halpern, K. Millis, A. C. Graesser, H. Butler, C. Forsyth, and Z. Cai, "Operation ARA: A computerized learning game that teaches critical thinking and scientific reasoning," Think. Ski. Creat., vol. 7, no. 2, pp. 93-100, 2012, doi: 10.1016/j.tsc.2012.03.006.

[12] J. E. Dowd, T. Duncan, and J. A. Reynolds, "Concept maps for improved science reasoning and writing: Complexity isn't everything," CBE Life Sci. Educ., vol. 14, no. 4, pp. 1-6, 2015, doi: 10.1187/cbe.15-06-0138.

[13] L. Luzyawati, "Implementasi Model Project Based Learning pada Materi Pencemaran Air untuk Meningkatkan Kemampuan Berpikir Kreatif Siswa," Unnes J. Biol. Educ., vol. 5, no. 1, pp. 100-109, 2016.

[14] J. Han, "Scientific reasoning: Research, development, and assessment." The Ohio State University, 2013.

[15] C. J. Wenning and R. E. Vieyra, "Teaching high school Physics," Released on Kindle March, vol. 25, p. 2015, 2015.

[16] D. G. Moursund, Project-based learning using information technology. International society for technology in education Eugene, OR, 1999.

[17] D. L. Sundre and A. D. Thelk, "Advancing assessment of quantitative and scientific reasoning," Numeracy, vol. 3 , no. 2, pp. $1-12,2010$.

[18] C. Gormally, P. Brickman, and M. Lutz, "Developing a test of scientific literacy skills (TOSLS): Measuring undergraduates' evaluation of scientific information and arguments," CBE-Life Sci. Educ., vol. 11, no. 4, pp. 364-377, 2012.

[19] A. E. Lawson, "The development and validation of a classroom test of formal reasoning," J. Res. Sci. Teach., vol. 15, no. 1, pp. 11-24, 1978.

[20] D. V. R. W. Charysma, S. Widoretno, and S. Widiastuti, "Analisis Konten Konteks Buku Referensi Biologi Materi Sistem Imun Berdasarkan Aspek Pemecahan Masalah dan Penalaran Ilmiah," vol. 10 , no. 2, pp. 295-300, 2018.

[21] R. Kusumaningrum, "Profil Penalaran Permasalahan Analogi Siswa Sekolah Menengah Pertama Ditinjuau Dari Perbedaan Gender," MATHEdunesa, vol. 2, no. 3, 2013.

[22] L. Lissa, A. P. B. Prasetyo, and D. R. Indriyanti, "Pengembangan Instrumen Penilaian Keterampilan Berpikir Tingkat Tinggi Materi Sistem Respirasi Dan Ekskresi," Lembaran Ilmu Kependidikan, vol. 41, no. 1, 2012.

[23] L. Kambeyo, "Scientific Reasoning Skills: a Theoretical Background on Science," no. January 2017, 2018.

[24] C. L. Chiang and H. Lee, "The Effect of Project-Based Learning on Learning Motivation and Problem-Solving Ability of Vocational High School Students," Int. J. Inf. Educ. Technol., vol. 6, no. 9, pp. 709-712, 2016, doi: 10.7763/ijiet.2016.v6.779.

[25] C. F. Pasani and M. Basil, "Mengembangkan Karakter Tanggung Jawab Siswa Melalui Pembelajaran Matematika dengan Model Kooperatif Tipe TAI di Kelas VIII SMPN," EDU-MAT J. Pendidik. Mat., vol. 2, no. 2, pp. 219-229, 2014, doi: 10.20527/edumat.v2i2.616.

[26] D. Kurniati, R. Harimukti, and N. A. Jamil, "Kemampuan Berpikir Tingkat Tinggi Siswa Smp Di Kabupaten Jember Dalam Menyelesaikan Soal Berstandar Pisa," J. Penelit. dan Eval. Pendidik., vol. 20, no. 2, p. 142, 2016, doi: 10.21831/pep.v20i2.8058.

[27] E. Prasetyani, Y. Hartono, and E. Susanti, "Kemampuan Berpikir Tingkat Tinggi Siswa Kelas Xi Dalam Pembelajaran Trigonometri Berbasis Masalah Di Sma Negeri 18 Palembang," J. Gantang, vol. 1, no. 1, pp. 34-44, 2016, doi: 10.31629/jg.v1i1.4.

[28] R. A. Ardani and F. A. Ningtiyas, "Peran Berpikir Analogi Dalam Memecahkan Masalah Matematika," 2017.

[29] A. Arcat, "Kemampuan Penalaran Siswa Kelas VII SMP Kecamatan Tambusai Tahun 2017," Edu Res., vol. 6, no. 2, pp. 34 42, 2017.

[30] W. O. L. Arisanti, W. Sopandi, and A. Widodo, "Analisis Penguasaan Konsep dan Keterampilan Berpikir Kreatif Siswa SD Melalui Project Based Learning," EduHumaniora| J. Pendidik. Dasar Kampus Cibiru, vol. 8, no. 1, pp. 82-95, 2016.

[31] Ermayanti, Y. Anwar, and D. Zein, "Analyzing scientific reasoning skills of biology prospective teachers," J. Phys. Conf. Ser., vol. 1166, no. 1, 2019, doi: 10.1088/1742-6596/1166/1/012002.

[32] L. Bao et al., "Physics: Learning and scientific reasoning," Science (80-. )., vol. 323, no. 5914, pp. 586-587, 2009, doi: 10.1126/science. 1167740 .

[33] S. C. Cheng, H. C. She, and L. Y. Huang, "The impact of problemsolving instruction on middle school students' physical science learning: Interplays of knowledge, reasoning, and problem solving," Eurasia J. Math. Sci. Technol. Educ., vol. 14, no. 3, pp. 731-743, 2018, doi: 10.12973/ejmste/80902. 